\title{
Diversity and seasonal fluctuation of predominant microbial communities in Bhitarkanika, a tropical mangrove ecosystem in India
}

\author{
Rashmi Ranjan Mishra1 ${ }^{1}$ Manas Ranjan Swain ${ }^{2}$, Tushar Kanti Dangar ${ }^{3} \&$ Hrudayanath Thatoi*2 \\ 1. Department of Biotechnology, MITS School of Biotechnology, Bhubaneswar 751024, Odisha, India; \\ rashmiranjan93@gmail.com \\ 2. Department of Biotechnology, College of Engineering and Technology, Bhubaneswar 751003, Odisha, India; \\ hn_thatoi@rediffmail.com, manas.swain@gmail.com \\ 3. Microbiology Laboratory, Division of Crop Production, Central Rice Research Institute, Cuttack, 753006, Odisha, \\ India; dangartk@rediffmail.com
}

Received 15-VI-2011. C Corrected 20-X-2011. Accepted 28-XI-2011.

\begin{abstract}
Different groups of microorganisms are present in mangrove areas, and they perform complex interactions for nutrient and ecological balances. Since little is known about microbial populations in mangroves, this study analyzed the microbial community structure and function in relation to soil physico-chemical properties in Bhitarkanika, a tropical mangrove ecosystem in India. Spatial and seasonal fluctuations of thirteen important groups of microorganisms were evaluated from the mangrove forest sediments during different seasons, along with soil physico-chemical parameters. The overall microbial load $\left(\mathrm{x} 10^{5} \mathrm{cfu} / \mathrm{g}\right.$ soil) in soil declined in the order of heterotrophic, free living $\mathrm{N}_{2}$ fixing, Gram-negative nitrifying, sulphur oxidizing, Gram-positive, spore forming, denitrifying, anaerobic, phosphate solubilizing, cellulose degrading bacteria, fungi and actinomycetes. Populations of the heterotrophic, phosphate solubilizing, sulphur oxidizing bacteria and fungi were more represented in the rainy season, while, Gram-negative, Gram-positive, nitrifying, denitrifying, cellulose decomposing bacteria and actinomycetes in the winter season. The pool size of most of other microbes either declined or maintained throughout the season. Soil nutrients such as $\mathrm{N}, \mathrm{P}, \mathrm{K}(\mathrm{Kg} / \mathrm{ha})$ and total $\mathrm{C}(\%)$ contents were higher in the rainy season and they did not follow any common trend of changes throughout the study period. Soil $\mathrm{pH}$ and salinity $(\mathrm{mS} / \mathrm{cm})$ varied from 6-8 and 6.4-19.5, respectively, and they normally affected the microbial population dynamics. Determination of bacterial diversity in Bhitarkanika mangrove soil by culture method showed the predominance of bacterial genera such as Bacillus, Pseudomonas, Desulfotomaculum, Desulfovibrio, Desulfomonas, Methylococcus, Vibrio, Micrococcus, Klebsiella and Azotobacter. Principal component analysis (PCA) revealed a correlation among local environmental variables with the sampling locations on the microbial community in the mangrove soil. Rev. Biol. Trop. 60 (2): 909-924. Epub 2012 June 01.
\end{abstract}

Key words: mangrove ecosystem, microbial population, soil nutrient content, seasonal variation.

Mangroves are typically tropical and subtropical coastal ecosystems of the inter-tidal zones of river deltas and backwater areas. They are mostly moderately saline habitats and are dynamic ecotones between land and sea with fluctuating temperature, tidal regime and salinity. Mangrove forests dominate one-quarter of the world's tropical coastline. Despite being fragile and sparsely distributed ecosystems, they are highly productive all over the world
(Thatoi \& Biswal 2008). They are primary producers of organic matter and provide a base for a large and complex food web (Zhang et al. 2009). Richness in carbon and other nutrients support large number of microbial communities whose activity is responsible for major nutrient transformations within a mangrove ecosystem (Alongi et al. 1993, Holguin et al. 2001). These microorganisms decompose organic matter by both aerobic and anaerobic 
processes and produce protein rich detritus that serves as food for other organisms (Steinke 2000). Various groups of bacteria like nitrogen fixers, phosphate solubilizers, cellulose decomposers, nitrifiers and denitrifiers, sulphur oxidizers, iron oxidizers and iron reducers are usually present in mangrove environment (Holguin et al. 2001). Complex interactions among these microbes maintain the nutritional status and ecological balance of these mangroves (Holguin et al. 2006).

Among different groups of microorganisms, bacteria are known to be important degraders of organic matter and they control the recycling of essential nutrients in coastal sediments (Alongi 1994). Bacteria are responsible for most of the carbon flux in the mangrove sediment and act as carbon sink (Holguin et al. 2001), and they are also major participants in the nitrogen and phosphorus cycles in the mangroves (Rojas et al. 2001). Sulfate reducing bacteria i.e. Desulfovibrio, Desulfotomaculum, Desulfosarcina, Desulfococcus spp. among others are the primary decomposers and $\mathrm{N}_{2}$ fixing bacteria such as Azotobacter, Rhizobium spp. among others, recycle nitrogen in anoxic mangrove sediments (Chandrika et al. 1990). Furthermore, free living bacteria, fungi, and yeasts play a significant role in detritus formation in mangrove ecosystems (Maria \& Sridhar 2002). Some mangrove forests largely retain detritus within their sediments (i. g. as degradation or burial), while others lose a major fraction of their net primary production to adjacent coastal waters mainly through tidal forcing. Because of the regular tidal flooding and draining in many mangrove forests, the material exchange with adjacent waters can be very efficient (Kristensen et al. 2008).

Factors such as temperature, moisture and seasonality of temperature and moisture act to control wetland microbial activities, resulting in changes in key biogeochemical cycles (Gutknecht et al. 2006). Bacterial population in the mangrove sediment fluctuated depending on temperature, $\mathrm{pH}$, redox potential and salinity of water and sediments (Holguin et al. 2001). Diversity of microbial communities inhabiting in this unique swampy, saline, partially anaerobic environment is useful since it provides information of the microorganisms and their adaptability to such habitats (Semenov et al. 1999). Besides their ecological role, microbes from mangrove ecosystem possess unique capability to tolerate the hyper saline condition and contain useful enzymes, proteins, antibiotics and salt tolerant genes of much biotechnological significance (Lageiro et al. 2007). A more specific description of the bacterial diversity and distribution in a mangrove would improve our understanding of bacterial functionality and microbial interactions found in that ecosystem (Kathiresan \& Selvam 2006). Sediment is a pivotal component of aquatic ecosystems where important transformations and exchange processes are taking place (Levine et al. 2001). However, the knowledge of biogeochemical processes in sediments of tropical mangrove forests is still limited (Kristensen et al. 1998), particularly regarding the impact of changing nutrient levels. India has a total of $4827 \mathrm{~km}^{2}$ mangrove forests, which is $0.1 \%$ of the country's total geographical area and $5 \%$ of the world's mangrove vegetation (Kathiresan \& Rajendran 2005).

Bhitarkanika mangrove of Odisha, located in the confluence of the Brahmani and Baitarni rivers, is the second largest mangrove ecosystem in India (next to Sundarbans of West Bengal). It is considered as one of the top ranking mangrove forests of the world in terms of its rich biodiversity. These mangrove forests have high biological species diversity which is rated among one of the best in the world (Thatoi et al. 1999). An increasing reduction in mangrove vegetation is being witnessed due to deforestation and other developmental activities. Although many studies have been undertaken on flora and fauna of the mangrove ecosystem (Mishra et al. 1995, Gupta et al. 2005, Thatoi \& Biswal 2008) the microbial diversity analysis of this Indian mangrove system has been grossly ignored and the scientific basis of the bio-geochemical cycles of the habitat is not yet been understood. Therefore, the diversity and seasonal fluctuations of predominant 
microbial communities of Bhitarkanika was assessed to understand the prevailing functional diversity of the microbial processes and the microbial ecology which would help to understand and develop strategies for sustenance of the ecosystem. It was also attempted to correlate soil physico-chemical parameters with the microbial population in the Bhitarkanika mangrove ecosystem.

\section{MATERIALS AND METHODS}

Study site: The microbial studies of the Bhitarkanika Wildlife Sanctuary (20 $30^{\circ} "$ $20^{\circ} 50^{\prime \prime} \mathrm{N}$ latitude and $86^{\circ} 30^{\prime \prime}-87^{\circ} 6^{\prime \prime} \mathrm{E}$ longitudes) of Odisha, India, were undertaken at five different locations: Rangani (Site 1), Mahisamunda (Site 2), Habalaganda (Site 3), Dangamal (Site 4) and Kalibhanjadian (Site 5) (Fig. 1), and the four seasons: rainy (JuneJuly), autumn (October-November), winter (December-January) and summer (April-May) of 2007-2008.

For soil physico-chemical and microbial analysis, approximately $100 \mathrm{~g}$ of soil samples were collected from five arbitrarily selected spots of each of the five locations. Samples were removed of the $10 \mathrm{~cm}$ top soil sediments, and the quintuplicate samples (over one $\mathrm{m}^{2}$ area) were mixed thoroughly in sterile polythene bags and brought to Microbiology Laboratory, North Odisha University, Odisha for further analysis.

Soil $\mathrm{pH}$ and EC were determined by suspending $50 \mathrm{~g}$ soil in $100 \mathrm{~mL}$ distilled and deionized water and shaken for one $h$ at 100rpm on a rotary shaker and then centrifuged at $10000 \times g$ for $5 \mathrm{~min}$. The $\mathrm{pH}$ and $\mathrm{EC}(\mathrm{mS} /$ $\mathrm{cm})$ of the supernatants were recorded with a digital $\mathrm{pH}$ and conductivity meters (model no 141, 341Systronics Pvt. Ltd., Ahamadabad, India), respectively. Total nitrogen content of the soil was determined by the Kjeidahl digestion method. Available phosphorus content of the soil was determined by flame photometer as per the procedures of Jackson (1973). For estimation of organic carbon, the soil samples were collected from $3-4 \mathrm{~cm}$ depth with the help of a spatula and transferred to the laboratory soon. The collected samples were first air-dried and successively oven dried at $60-65^{\circ} \mathrm{C}$. Dried samples were ground with a grinder to fine

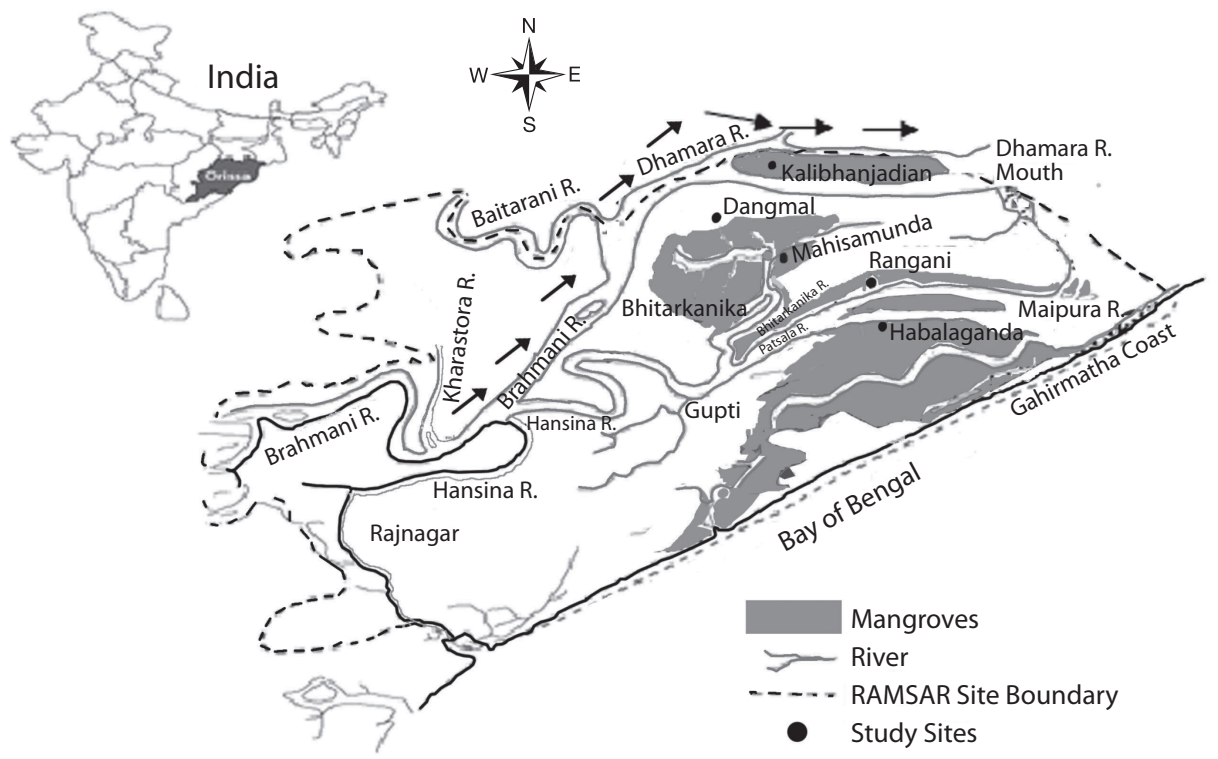

Fig. 1. Bhitarkanika study sites $(\bullet)$, Arrow mark indicates the direction of water flow in the river $(\rightarrow)$ 
powder and kept in a sterile polythene zip pack. Laboratory apparatus were acid soaked (Chromic acid) before the analysis, and afterwards were thoroughly rinsed with tap and distilled water, to ensure any traces of cleaning reagents. Surface sediments were air-dried followed by oven drying and after homogenization using pestle and mortar; it was passed through a $2 \mathrm{~mm}$ mesh screen and stored in polyethylene bags for further analysis. Organic carbon content of sediment samples were analyzed following methods of Jackson (1973).

One gram of air dried soil was diluted up to $10^{-5}$ in sterilized (autoclaved at $121^{\circ} \mathrm{C}, 15 \mathrm{~min}$ ) distilled water, $100 \mu \mathrm{L}$ of the suspensions were separately spread plated on petri plates $(n=5)$ containing different media and incubated at $30 \pm 0.1^{\circ} \mathrm{C}$ in an incubator. Heat-treated $\left(60^{\circ} \mathrm{C}\right.$, $30 \mathrm{~min}$ ) soil suspensions were used to enumerate the spore-forming bacteria. Colony forming units (cfu) of the microbes were counted under a colony counter. Heterotrophic, Gram-negative and spore-forming bacteria were enumerated on nutrient agar (NA). Gram-negative bacteria were enumerated on NA medium containing sterilized aqueous crystal violet $(0.01 \mathrm{~g} / \mathrm{L})$ (Pelczar et al. 1957). Nitrifying and denitrifying bacteria were enumerated on Winogradsky's medium (Pelczar et al. 1957) (g/L: $\mathrm{K}_{2} \mathrm{HPO}_{4}$ 1, $\mathrm{NaCl} 2, \mathrm{MgSO}_{4} \cdot 7 \mathrm{H}_{2} \mathrm{O} 0.5, \mathrm{FeSO}_{4} \cdot 7 \mathrm{H}_{2} \mathrm{O}$ $0.001, \mathrm{CaCl}_{2} .2 \mathrm{H}_{2} \mathrm{O} 0.02,\left(\mathrm{NH}_{4}\right)_{2} \mathrm{SO}_{4} 1.00, \mathrm{pH}$ $8.5)$ and incubated at $30 \pm 0.1^{\circ} \mathrm{C}$ for seven-eight days. Nitrifying bacterial colonies appeared pink when the petri plates were flooded with sulphanillic acid reagent [equal volume mixture of sulphanillic acid $(8 \mathrm{~g} / \mathrm{Lin} 5 \mathrm{M}$ acetic acid) and $\alpha$-naphthyl amine $(5 \mathrm{~g} / \mathrm{Lin} 5 \mathrm{M}$ acetic acid)]. The asymbiotic nitrogen-fixing bacteria were cultured on nitrogen-free medium $(\mathrm{g} / \mathrm{L}$ : mannitol 10, $\mathrm{K}_{2} \mathrm{HPO}_{4} 0.5, \mathrm{MgSO}_{4} .7 \mathrm{H}_{2} \mathrm{O} 0.2$, $\mathrm{NaCl} 0.2, \mathrm{MnSO}_{4} \cdot 4 \mathrm{H}_{2} \mathrm{O} 0.01, \mathrm{FeCl}_{3} 0.001$, agar 18, pH 7.2) (Pelczar et al. 1957). Sulfuroxidizing bacteria (brown colonies), soil fungi and actinomycetes were counted on Thiobacillus medium $\left(\mathrm{g} / \mathrm{L}: \mathrm{Na}_{2} \mathrm{~S}_{2} \mathrm{O}_{3}\right.$ 0.5, $\left(\mathrm{NH}_{4}\right)_{2} \mathrm{SO}_{4}$ $0.4, \mathrm{KH}_{2} \mathrm{PO}_{4} 4, \mathrm{CaCl}_{2} 0.25, \mathrm{MgSO}_{4} .7 \mathrm{H}_{2} \mathrm{O}$ $0.5, \mathrm{FeSO}_{4} 0.01$, agar 18), mycological agar medium (g/L: peptic digest of soyabean meal
10, dextrose 40, agar 18, pH 7) and Krainsky's medium (Pelczar et al. 1957) (g/L: glucose 10 , asparagine $0.5, \mathrm{~K}_{2} \mathrm{HPO}_{\mathrm{e}} 0.5$, agar $15, \mathrm{pH}$ 7 ), respectively. The bacterial isolates, those formed halo zones on insoluble phosphatecontaining medium $\left(\mathrm{g} / \mathrm{L}\right.$ : glucose $10, \mathrm{Ca}_{3}$ $\left(\mathrm{PO}_{4}\right)_{2} 5, \mathrm{MgSO}_{4} .7 \mathrm{H}_{2} \mathrm{O} 0.25, \mathrm{MgCl}_{2} 5, \mathrm{KCl}$ $0.2,\left(\mathrm{NH}_{4}\right)_{2} \mathrm{SO}_{4} 0.1$, agar 18) were counted as phosphate-solubilizing microbes (Nautiyal 1999). Morpho-physiological and biochemical characters such as shape, size, Gram staining, indole production oxidase, catalase, urease hydrolysis, acid from glucose, mannitol, arabinose, xylose, citrate, and propionate utilization and tyrosine hydrolysis were studied. Besides, assays like casein, gelatin, and starch hydrolysis were also checked and the bacterial isolates were identified as per Bergey's Manual of Systematic Bacteriology (Sneath 1986). Principal Component Analysis (PCA) using SPSS13 statistical software did ordination of data matrices for physico-chemical properties of soil and seasonal variation of population of 13 different groups of bacteria. For evaluation of analytical results, multivariate statistical methods of correlation analysis and PCA were applied.

\section{RESULTS}

Soil physico-chemical properties $(\mathrm{pH}, \mathrm{EC}$, $\mathrm{N}, \mathrm{P}, \mathrm{K}$ and $\mathrm{C}$ ) and 13 groups of microbial populations of five different sites of Bhitarkanika mangroves of India were studied during four different seasons. The $\mathrm{pH}$ of different sites was limited within a narrow range of 6.02-7.89 which was acidic (6.0-6.6) during the winter but neutral to marginally alkaline in the other seasons (Fig. 2a). Soil redox potential (E.C) was comparable in different seasons but was almost double in the summer (Fig. 2b). Total $\mathrm{N}$ content of the five sites ranged between 200.6-285.5kg/ha (Fig. 2c) and did not vary significantly in any given season. However, it gradually declined from the rainy through the summer season. The $\mathrm{P}$ content followed a similar trend and varied from $9.0-24.0 \mathrm{~kg} / \mathrm{ha}$ among sites. The P level was maximum $(24.00 \mathrm{~kg} / \mathrm{ha})$ at site four, and minimum $(9.80 \mathrm{~kg} / \mathrm{ha})$ at site 

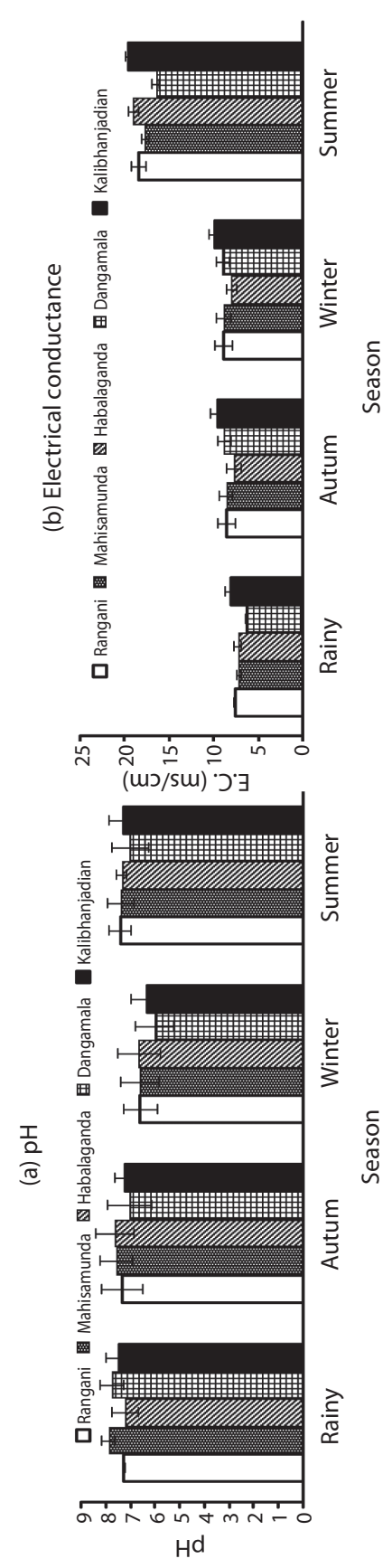
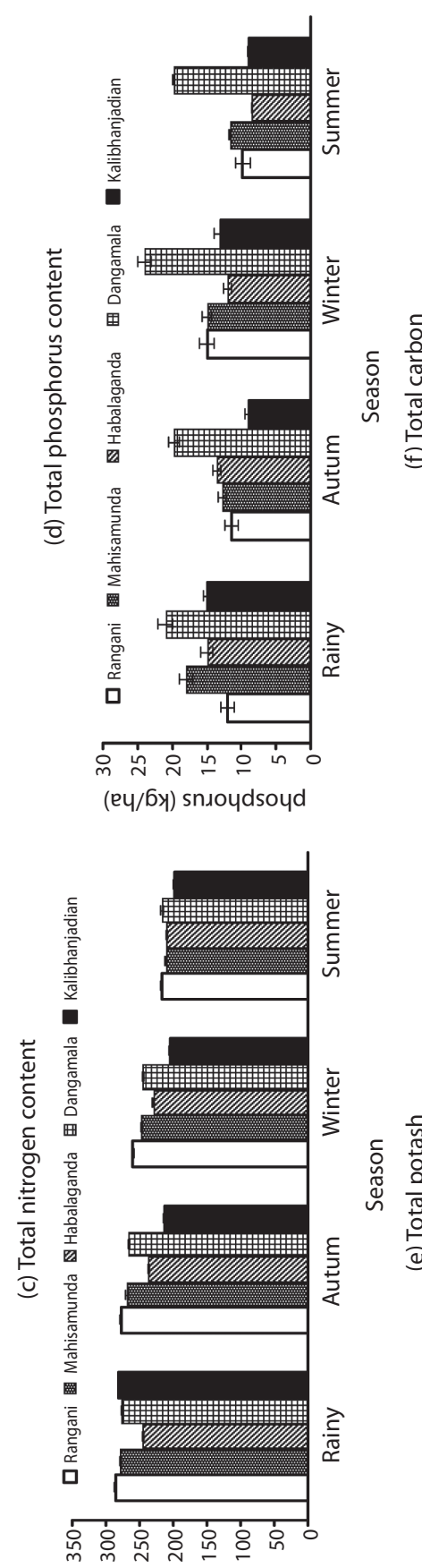

(еч/бу) uәбоג!! N

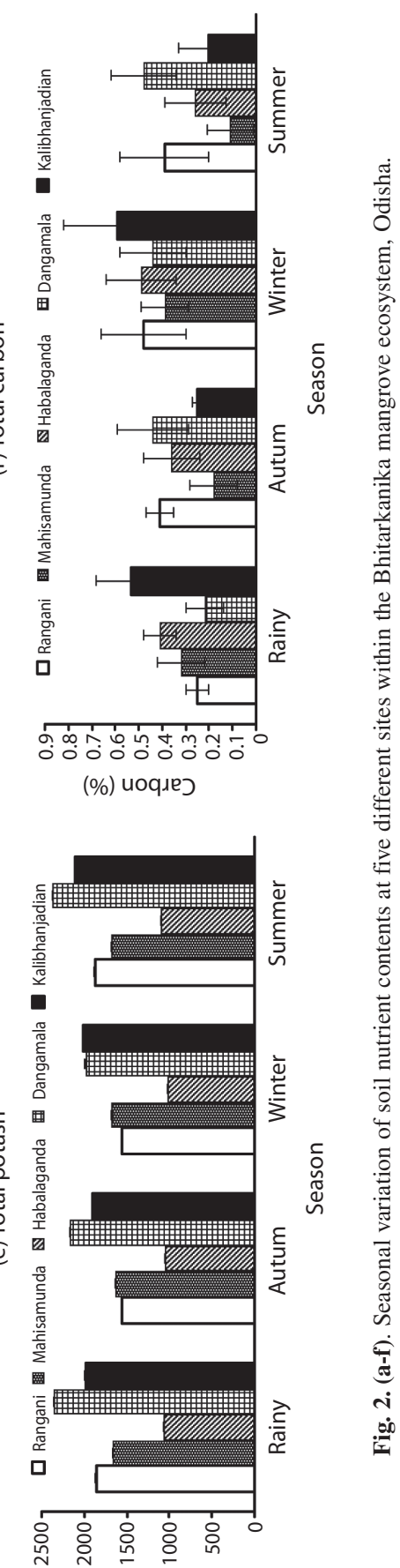

(еч/бу) ysezod 
one (Fig. 2d). The $\mathrm{K}$ level varied within the range of $1053-2378 \mathrm{~kg} / \mathrm{ha}$ among sites and was two-five times more in the rainy season (Fig. 2e). Total carbon (C) content of the sites (0.11-0.59\%) did not follow any common seasonal trend, but was maximum in winter and minimum in autumn (Fig. 2f).

Bacterial populations (heterotrophic, $\mathrm{N}_{2}$ fixing, Gram-negative, nitrifying, $\mathrm{S}$ oxidizing, Gram-positive, spore forming, denitrifying, $\mathrm{P}$ solubilizing, anaerobic and cellulose degrading and actinomycetes did not change coherently with season or site (Figs. 3). Seasonally the heterotrophic bacterial population $138-413$ ( $\times 10^{5} \mathrm{cfu} / \mathrm{g}$ soil) was more than the other microbes while, during rainy season, it increased by about 1.5-2.5, 2-2.1, 1.5-3, 1.1-1.5 and 1.1-1.4 times at the sites two, one, four, five and three), respectively (Fig. 3a).

Generally, the heterotrophic, P solubilizing and $\mathrm{S}$ oxidizing populations were maximum in the rainy season, when pool size of most of the other microbes either declined or maintained (Figs. 3a, d, i). The $\mathrm{N}_{2}$ fixing bacterial population was $117-135.7$ (x10 $10^{5} \mathrm{cfu} / \mathrm{g}$ soil) during the rainy season (Fig. 3g). However, in the same season the spore forming bacterial population was comparatively less and varied from $11-21.7$ (x10 $\mathrm{cfu} / \mathrm{g}$ soil) (Fig. 3h). Nitrifying bacterial population varied between 22.00$75.66\left(\times 10^{5} \mathrm{cfu} / \mathrm{g}\right.$ soil $)$ in different locations throughout the seasons and in the rainy season, increased by about two folds at site five, while other sites maintained the population level (Fig 3f). The denitrifying bacteria varied from $10.33-32.00\left(\times 10^{5} \mathrm{cfu} / \mathrm{g}\right.$ soil $)$ in different locations through out the season (Fig. 3e). The different sites harbored $4.00-24.33 \times 10^{5} \mathrm{cfu} / \mathrm{g}$ soil anaerobic bacteria in different seasons (Fig. $3 \mathrm{k}$ ), which declined from winter through the rainy season in all sites but increased abruptly at sites one and four (Fig. 3k). Gram-negative bacteria varied between $44-175 \times 10^{5} \mathrm{cfu} / \mathrm{g}$ soil in different sites, which declined in all sites but more at site two during rainy season (Fig. 3b). However, at site 4 the population was comparable in all seasons (Fig. 3b). Gram-positive bacterial abundance was $4.5-94.7 \times 10^{5} \mathrm{cfu} / \mathrm{g}$ soil in different sites and seasons (Fig. 3c) with a population peak during the rainy season only at site 5 (Fig. 3c). At sites 1, 2 and 3 the spore forming bacterial population followed a common trend which was more $15-37.5 \times 10^{5} \mathrm{cfu} / \mathrm{g}$ soil in the winter, and declined by 45-50 fold in the summer (Fig. 3h). The same trend was followed at site 4, which increased gradually in the autumn (Fig. 3h). The P solubilizing bacteria fluctuated between $2.2-15.7$ (x105 $\mathrm{cfu} / \mathrm{g}$ soil) followed the same trend and pool size in winter, summer and autumn seasons which was maximum during the rainy season (four-nine cfu/g soil x $10^{5}$ ) (Fig. 3d). The $\mathrm{P}$ solubilizing population was two-five times more in sites 2 and 3 respectively, than that of site 1 (x10 $6.4-15.7 \mathrm{cfu} / \mathrm{g}$ soil) (Fig 3d). Cellulose degrading bacteria declined from winter through the summer, except for sites 4 and 5 which increased and decreased alternately (Fig. 3j). The actinomycetes profile was comparatively very lower compared to other microorganisms and maintained a same trend which declined from winter through the rainy season followed by an increase towards autumn at all sites (Fig. 31). Based on culturable methods, a number of bacteria were isolated from Bhitarkanika mangrove soil and identified phenotypically following standard biochemical tests. The predominant bacterial genera identified were Bacillus, Pseudomonas, Desulfotomaculum, Desulfovibrio, Desulfomonas, Methylococcus, Vibrio, Micrococcus, Klebsiella and Azotobacter.

In this study, PCA was employed to explore how the changes in the microbial community composition varied with environmental conditions, which has been proven to be sensitive in detecting the relationship between bacterial community composition and environmental parameters. Using PCA, the original variables during rainy season were reduced to four principal components (PC1-PC4), which had Eigen values larger than one and retained for rotation (Figs 4a-e). PC1 accounted for $36 \%$, where PC2, PC3, PC4 accounted for $30 \%, 20 \%$ and $12 \%$, respectively. The combined PC1-PC4 together accounted for $94 \%$ of the total variation (Table 1). The total 19 

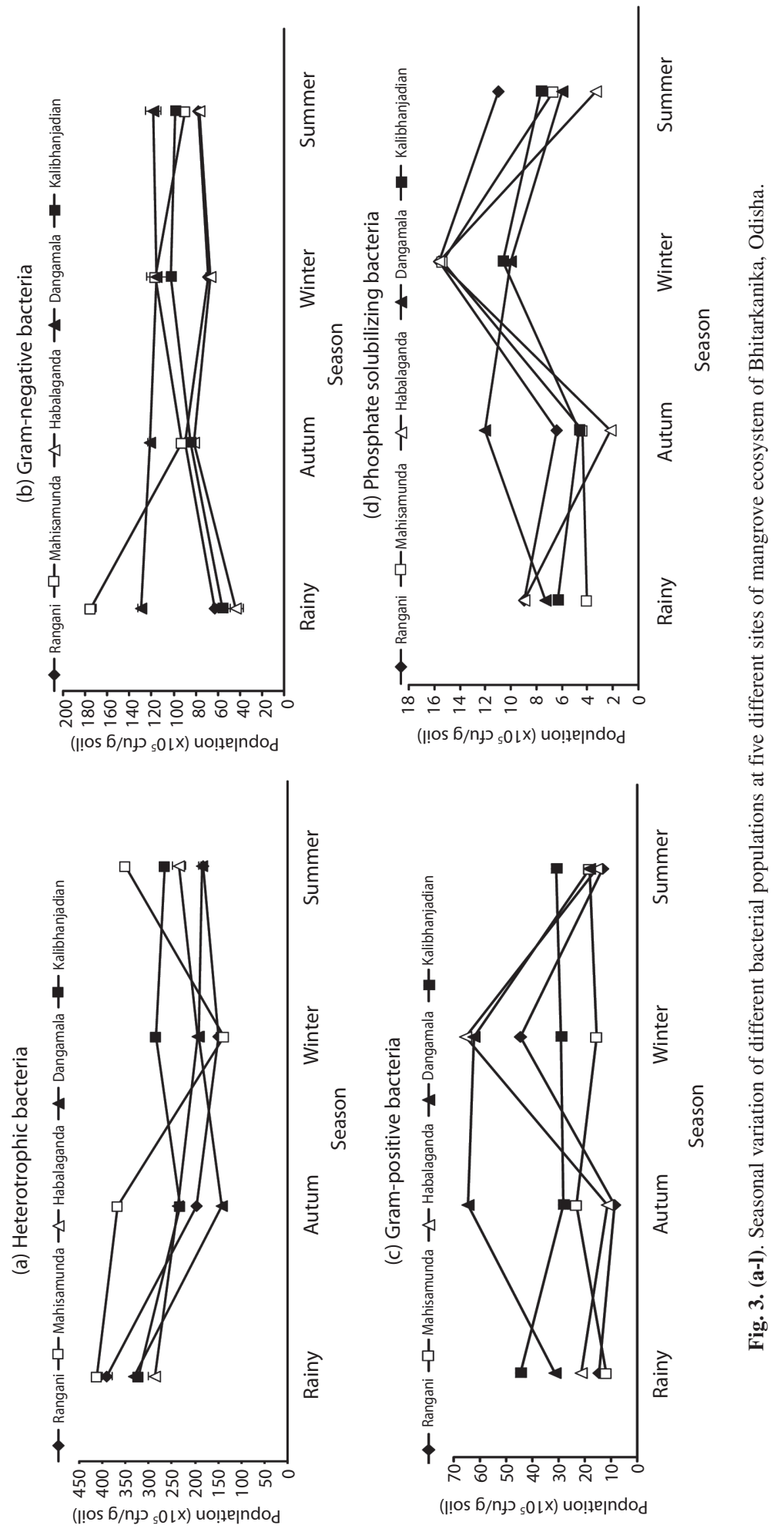


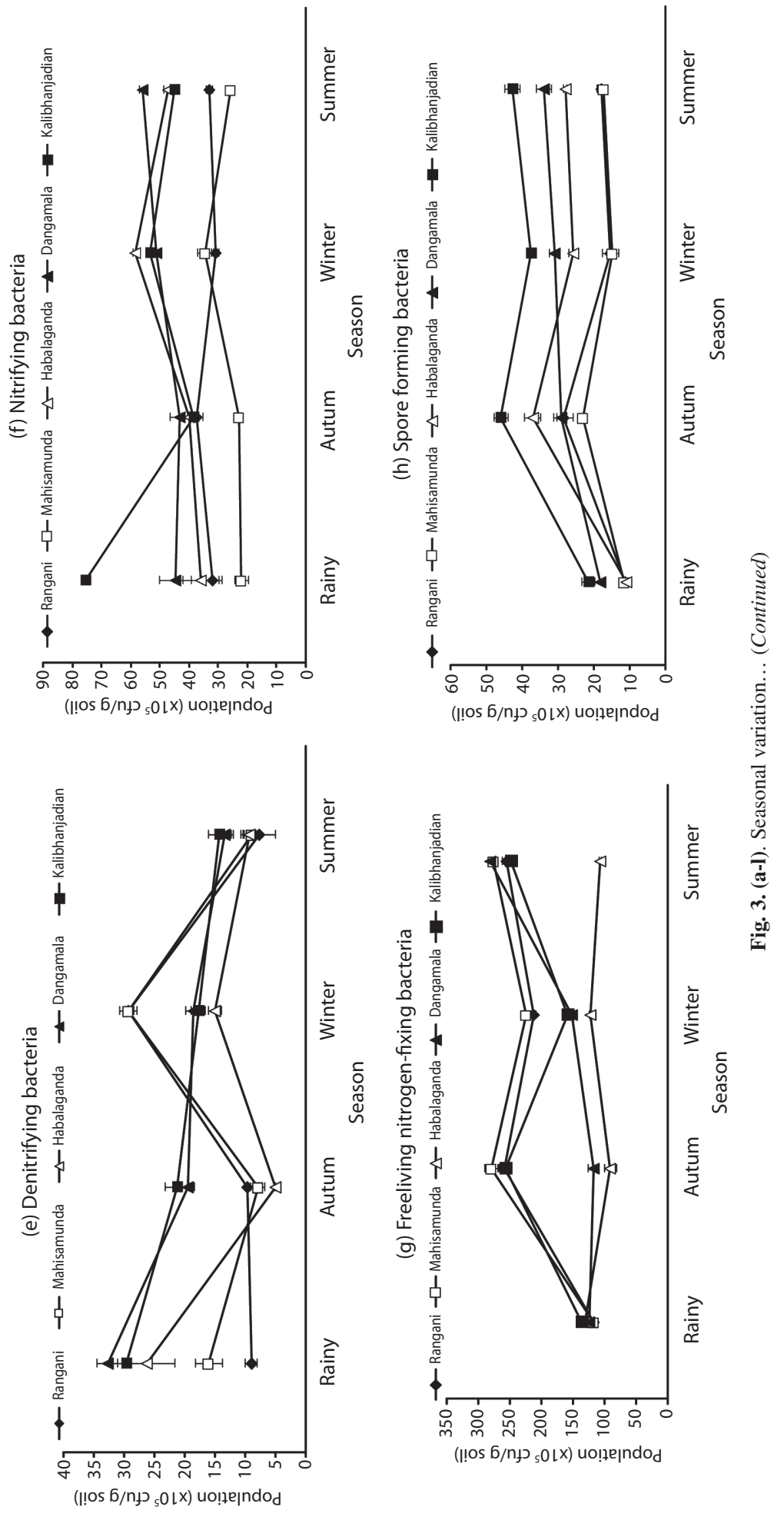




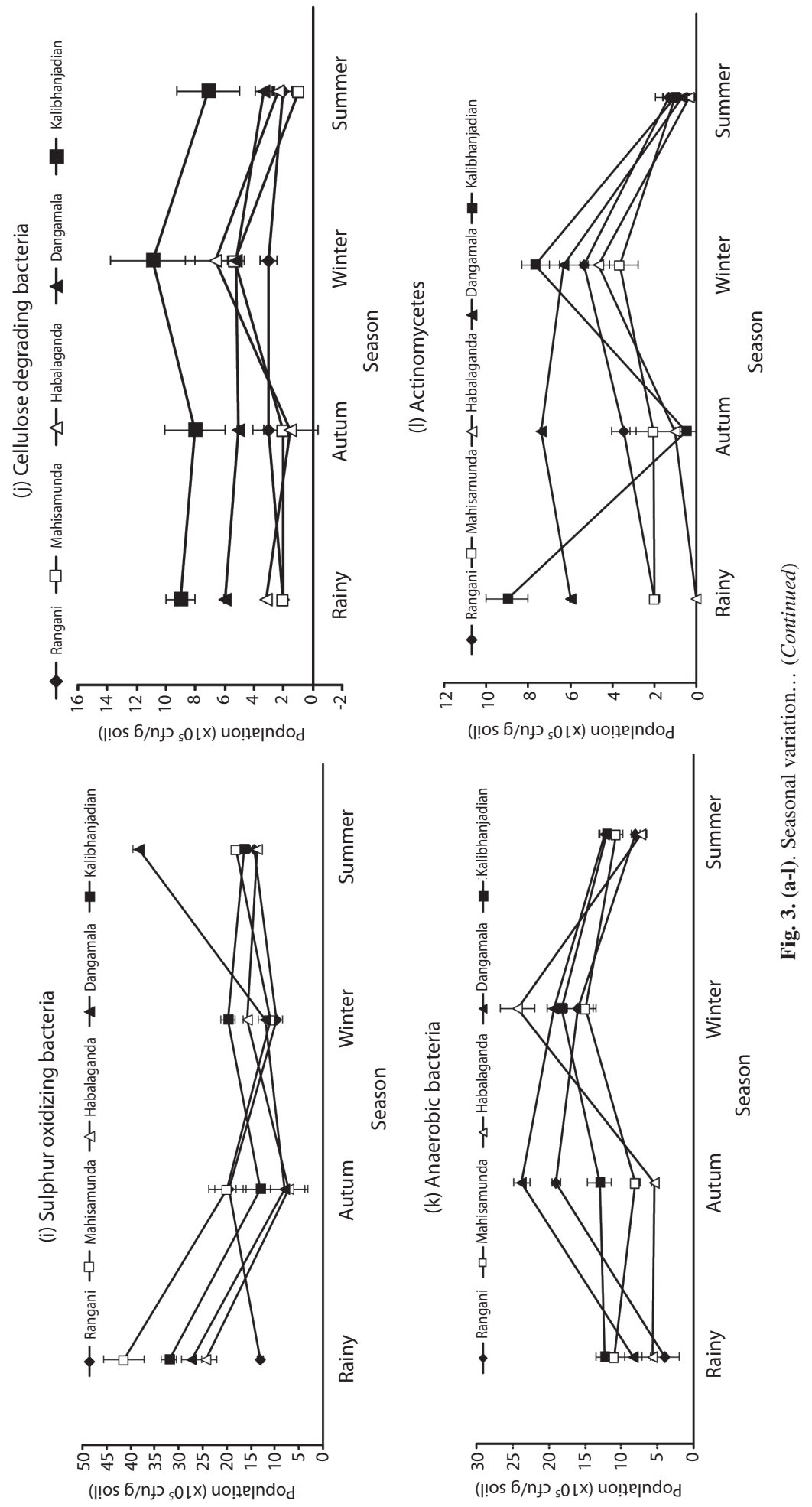




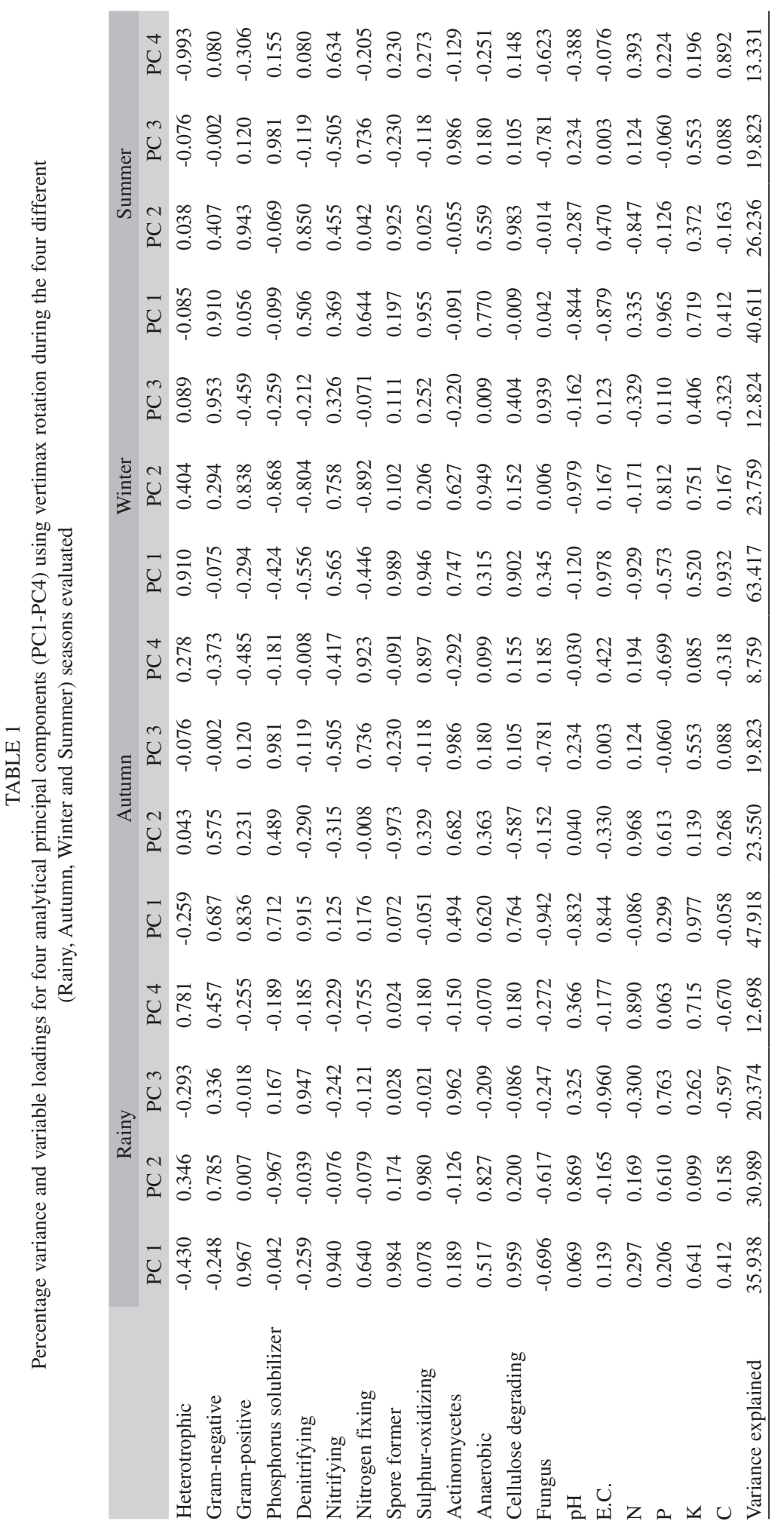



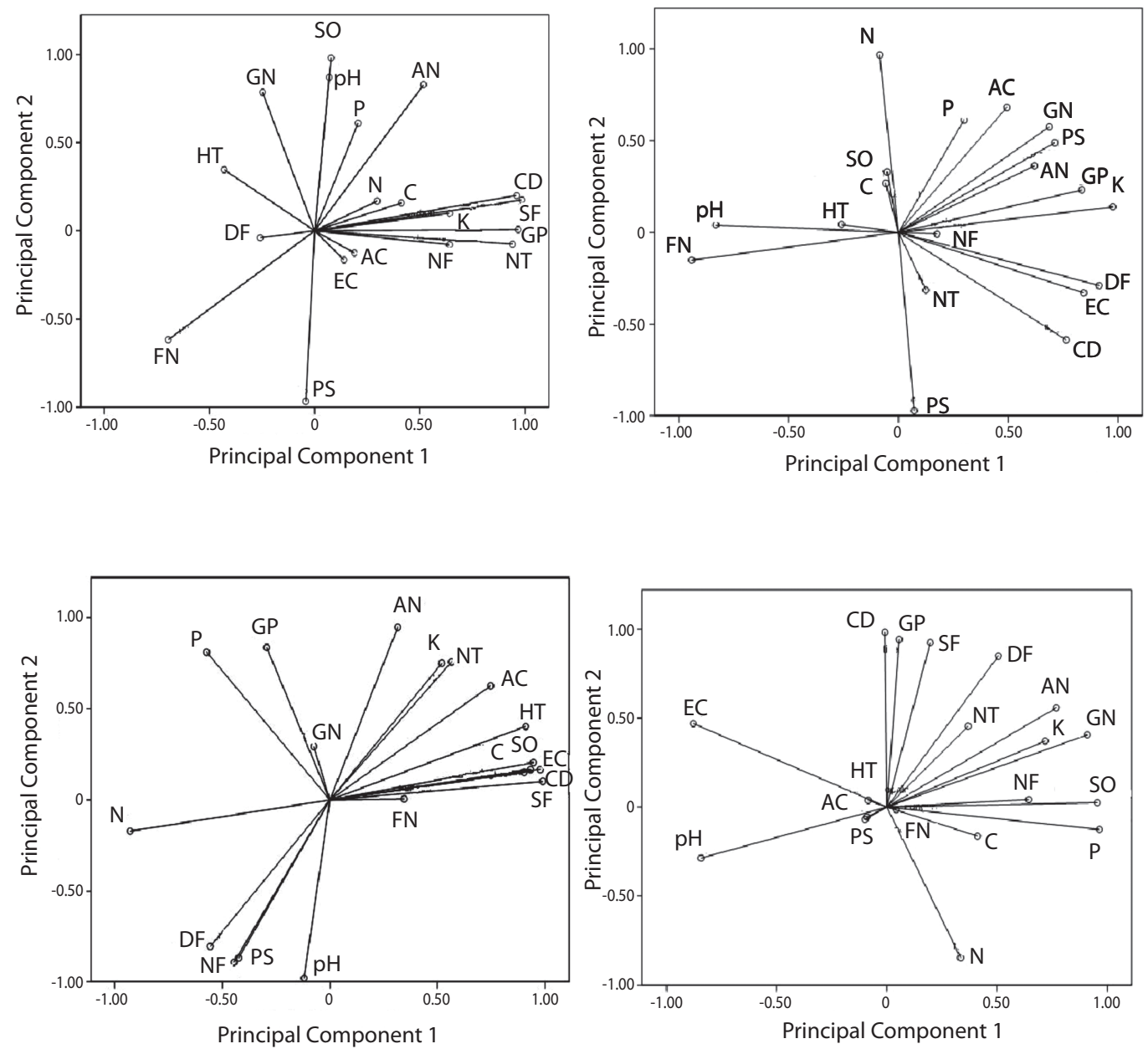

Fig. 4. (a-d). Principal components (PC1 vs. PC2) of proximate variables. Abbreviations: SO: Sulphur oxidizing; PS: Phosphate solubilizing; NF: $\mathrm{N}_{2}$ fixing; NT: Nitrifying; DF: Denitrifying; EC: Electrical Conductance; N: Total Nitrogen; K: Total Phosphorus; C: Total carbon; CD: Cellulose degrading bacteria; SF: Spore forming; AC: Actinomycetes; GP: Gram positive; GN: Gram negative; AN: Anaerobic; P: total phosphorus pH: pH of soil; FN: Fungus, HT: Heterotrophic, HT: Heterotrophic for rainy (A), autumn (B), winter (C) and summer (D) season.

proximate variables loaded heavily in four dimensions, while the loading of carbon and nitrifying microorganisms did not meet the Stevenson's guide line $(<0.72)$. To assist the interpretation of dimensions, the factor pattern was rotated using vertimax method. Based on the guidelines provided by Stevans (1992) an attribute is considered to load heavily on a giving component if the factor loading is greater than 0.72 . The analytical variables,
Gram-positive, nitrifying (+)ve, spore forming $(+) v e$, cellulose degrading $(+)$ ve were loaded heavily on PC1 indicating the strong correlation among the variables. The population axis and these components were responsible for the major microflora load during the rainy season. The original variables during autumn season were reduced to four PC. Then PC1 accounted for $48 \%$, while the combined PC accounted for $98 \%$ of the total variation (Table 1 ). The total 
19 proximate variables loaded heavily in a four dimension while Gram-negative, actinomycetes, anaerobic, phosphorus bacteria did not meet the Stevenson's guide line. During winter, original variables were reduced to three PC. The PC1 accounts for $63 \%$ and combined PC accounts for $98 \%$ of the total variation (Table 1). The original variables were reduced to four $\mathrm{PC}$ during summer season. PC1 accounted for $40 \%$ whereas PC2, PC3 and PC4 accounted for $26 \%, 19 \%$ and $13 \%$, respectively (Table 1). Gram-negative bacteria (+)ve, sulphur oxidizing (+)ve, anaerobic (+)ve, pH (-)ve, E.C. (-)ve, phosphorus $(+)$ ve loaded heavily which contributed strong relation among the variables.

\section{DISCUSSION}

Mangrove ecosystem environmental parameters affecting the community of soil bacteria have been detailed over many years (Holguin et al. 2001). In the present study, soil $\mathrm{pH}$ variation of the Bhitarkanika mangrove sediment on different seasons agrees the observations of Essien et al. (2006), who have recorded acidic $\mathrm{pH}$ (6.36) in the rainy season in mangrove sediment of Qua Iboe Estuary. However, it contradicts with the observations by Gonzalez- Acosta et al. (2006) who noted slightly alkaline $\mathrm{pH}$ (7.8) in the Mexican mangrove forest. Nevertheless, conductivity limits $(2.9-17.69 \mathrm{mS} / \mathrm{cm})$ of the Bhitarkanika mangrove sediment is in favour of the observation of Essien et al. (2006) who have recorded a nearly equal value of conductivity from Qua Iboe Estuary. The high levels of N, P and $\mathrm{K}$ (245-285, 12-21 and $663-1075 \mathrm{~kg} / \mathrm{ha}$, respectively) in the rainy season are in support of the view of Essien et al. (2006) that runoff water may leach the minerals to the mangrove sediment, estuaries and tidal zones. Unlike other nutrients, carbon level was maximum in the rainy season, and this is attributed to replenishment by the runoff water (Martinez et al. 1996).

The non-coordinated local and seasonal variation of microbial populations in the mangrove habitat of the Bhitarkanika system agrees the non-coherent relation of the biotic and abiotic components of other mangrove ecologies (Martinez et al. 1996). Despite inherent limitations, viable count of microbial population was adapted in our study as it would reflect relatively abundant and functionally dominant microbial communities (Nannipieri et al. 2003, Das \& Dangar 2008). In spite of the higher salinity of mangrove soils, denitrifying bacteria $\left(10.712-22.016 \times 10^{5} \mathrm{cfu} / \mathrm{g}\right.$ soil) and asymbiotic $\mathrm{N}_{2}$ fixing bacteria $\left(125.2-213.6 \times 10^{5} \mathrm{cfu} / \mathrm{g}\right.$ soil) were high in all seasons and sites. Several authors are of the opinion that salinity is not the determining factor of microbial dynamics in mangroves (Essien et al. 2006). Contrary to inland or non-tidal coastal saline soils, average bacterial population in mangrove sediments was $1.8-2.1 \times 10^{6} \mathrm{cfu} / \mathrm{g}$ soils which were comparable to the population size $\left(2.2-6.0 \times 10^{6} \mathrm{cfu} / \mathrm{g}\right.$ soil) of non saline soils (Das \& Dangar 2008). However, Gonzalez-Acosta et al. (2006) have recorded more microbes $\left(10^{9}\right.$ $10^{11} \mathrm{cfu} / \mathrm{mL}$ water) in a Mexican mangrove forest. Sulphate may act as an electron acceptor during mineralization in saline soils (Zaharan 1997). Therefore, more sulphur-oxidizing bacteria may positively affect survival and growth of other microbes in saline soils. Relatively more nutrition $(\mathrm{N}, \mathrm{P}, \mathrm{K})$ in the rainy season would increase a microbial population. This was reflected, by increase in heterotrophic, phosphate solubilizing and sulphur oxidizing bacteria and fungal populations in the Bhitarkanika mangrove soil. Synergistic effect of the $\mathrm{P}$ and $\mathrm{N}$ levels would also augment the microbial population (Rojas et al. 2001). However, relatively lower populations of $\mathrm{P}$ solubilizing, spore forming, Gram-negative microbes in the rainy season could not be explained from the study. Decline of the heterotrophic community including $\mathrm{N}_{2}$ fixing bacteria, in the mangroves might be partially due to an increase in oxygen production during active growth of autotrophs and predation of the bacteria by the detritivores (Holguin et al. 1992, Toledo et al. 1995, Holguin et al. 2001). Decreased microbial diversity in winter months agrees the propositions that microbial populations were lower in winter and maximum in the summer 
(Martinez et al. 1996). In the soil, higher $\mathrm{P}$ level would be attributed to relatively more phosphate solubilizing bacteria whereas, lower nitrifying and denitrifying population would increase nitrogen levels and reduce the $\mathrm{N}_{2}$ fixing microbes. Close interactions usually exist between nitrogen and phosphorus solubilizing bacteria in soil ecosystem. It has been reported that interaction of $\mathrm{N}_{2}$ fixing bacteria with other bacteria can inhibit or promote their diazotrophic activity (Drozdowicz \& Santos 1987, Isopi et al. 1995). Similarly, the degradation of cellulose by Cellulomonas sp., have provided Azosprillum sp. with a usable carbon source to obtain energy for $\mathrm{N}_{2}$ fixation. Similarly, the synergism between $\mathrm{N}_{2}$ fixing Phyllobacterium sp. and phosphate solubilizing Bacillus licheniformis, both isolated from a semiarid mangrove rhizosphere has been reported by Rojas et al. (2001). Comparatively higher Gram- negative bacteria pool favored that they would be the sole decomposers. Minimum spore forming bacteria from heated inoculum but an overall increase in heterotrophs in the rainy season suggests that more bacteria would continue at growth phase due to enrichment of nutrition. Similarly, the anaerobic bacteria decrease in the rainy season as continuous turbulence increase $\mathrm{O}_{2}$ level in water. The Gram negative population and higher $\mathrm{O}_{2}$ level in sea water in the rainy season is in conformity with previous reports by Gonzalez-Acosta et al. (2006). Predominantly, clay and fine silt structure of the Bhitarkanika would enhance (up to two orders) diversity and density like other mangroves than in the sandy sediments (Sessitsch et al. 2001). Furthermore, lower nitrite and nitrate levels in the Bhitarkanika mangrove sediment are in support of other mangrove sediments with concomitant decline of nitrifying and denitrifying bacteria (Holguin et al. 1992).

However, microbial diversity of Bhitarkanika mangrove ecosystem has not been explored except for the reports on presence of Gram negative bacteria such as Pseudomonas, Desulfotomaculum and Methylococcus spp. (Mishra et al. 2009). In regards to its microbial diversity, Bhitarkanika mangrove ecosystem is largely dominated by Bacillus and Pseudomonas which is the characteristic of saline soil. Presence or absence of particular bacterial genera may depend on soil parameters, as observed by Alexander (1971). Although, there is considerable information how culturable bacteria respond to environmental variables in mangrove ecosystems (Takizaaqva et al. 1993, Wang \& Hong 2005), little is known about how these variables influence the structure of actual bacterial communities in the mangrove sediment.

Previous studies reported that the culturable bacteria composition has high similarity between mangrove soils collected from different mangrove areas (Shome et al. 1995). The present study revealed that the bacterial community compositions varied at different mangrove areas as well as seasons, and were both positively and negatively correlated with environmental factors. Environmental pH, E.C. and available phosphorus accounted for a significant amount of the variability in bacterial community composition. This indicates that organic matter content, $\mathrm{pH}$ and available soil phosphorus could influence the bacterial community structure in mangrove sediments.

Microbial dynamics and nutrition balance in the sediment of the Bhitarkanika mangrove forest are interdependent and salinity does not affect microbial functionalities. There is a prominent seasonal variation among the microbial population and the nutrient content. Sediment of Bhitarkanika mangrove forest harbors higher bacterial communities in comparison to fungi and actinomycetes exhibiting great genetic diversity. Mangrove soil supports higher population of free-living $\mathrm{N}_{2}$ fixers, nitrifiers, denitrifiers, phosphate solubilizer, cellulose degraders, and sulphur oxidizers, responsible for major biogeo-chemical cycles.

\section{ACKNOWLEDGMENTS}

The authors are grateful to the authorities of North Odisha University and Central Rice Research Institute for providing laboratory facilities to carry out the present work. The 
help and cooperation of staff from the Forest Department, Mangrove Forest Division, Rajanagar is gratefully acknowledged.

\section{RESUMEN}

En las zonas de manglares están presentes diferentes grupos de microorganismos, los cuales presentan complejas interacciones que afectan los balances ecológicos y de nutrientes. Debido a que se sabe poco sobre las poblaciones microbianas en los manglares, este estudio analiza la estructura y función de la comunidad microbiana según las propiedades físico-químicas del suelo en Bhitarkanika, un ecosistema de manglares tropicales en la India. Se evaluaron las fluctuaciones espaciales y temporales de 13 grupos de microorganismos importantes en el sedimento de los manglares durante diferentes temporadas y parámetros físico-químicos del suelo. La carga microbiana total (x105cfu/g de suelo) en el suelo se redujo en la categoría de las heterotróficas, de las bacterias libres fijadoras de $\mathrm{N}_{2}$, Gram-negativas nitrificantes, oxidativas de azufre, Gram-positivas, formadoras de esporas, desnitrificantes, anaeróbicas, las solubilizadoras de fosfato, bacterias degradadoras de celulosa, hongos y actinomicetos. Las poblaciones de heterótrofos, solubilizadoras de fosfato, oxidativas de azufre y los hongos estuvieron más representadas en la temporada lluviosa, mientras que, las Gram-negativas y Gram-positivas, nitrificantes, desnitrificantes, descomponedoras de celulosa y los actinomicetos, en la temporada de invierno. El tamaño poblacional de otros microorganismos disminuyó o se mantuvo durante toda la temporada. Los nutrientes del suelo, tales como N, P, K (Kg/ha) y el contenido total de $\mathrm{C}(\%)$ fueron mayores en la temporada de lluvias, y no siguieron ninguna tendencia común de cambio a través del período de estudio. El pH del suelo y la salinidad $(\mathrm{mS} / \mathrm{cm})$ variaron de 6-8 y $6.4-19.5$, respectivamente, lo que afectó significativamente la dinámica de la población microbiana. La determinación de la diversidad de bacterias en el suelo del manglar Bhitarkanika por el método de cultivo mostró el predominio de los géneros de bacterias como Bacillus, Pseudomonas, Desulfotomaculum, Desulfovibrio, Desulfomonas, Methylococcus, Vibrio, Micrococcus, Klebsiella y Azotobacter. El análisis de componentes principales (ACP) reveló una correlación entre las variables locales del ambiente y los sitios de muestreo en la comunidad microbiana en el suelo del manglar.

Palabras clave: mangrove ecosystem, microbial population, soil nutrient content, seasonal variation.

\section{REFERENCES}

Alongi, D.M., P Christoffersen \& F. Tirendi. 1993. The influence of forest type on microbial-nutrient relationships in tropical mangrove sediments. J. Exp. Mar. Biol. Ecol. 171: 201-223.

Alongi, D.M. 1994. The role of bacteria in nutrient recycling in tropical mangrove and other coastal benthic ecosystems. Mar. Ecol. Prog. Ser. 56: 133-144.

Alexander, M. 1971. Microbial ecology. Wiley, New York, USA.

Chandrika, V., P.V.R. Nair \& L.R. Khambhadkar. 1990. Distribution of phototrophic thionic bacteria in the anaerobic and micro- aerophilic strata of mangrove ecosystem of Cochin. J. Mar. Biol. Ass. India. 32: $77-84$

Gonzalez-Acosta, B., Y. Bashan, N.Y. Hernandez- Saavedra, F. Ascencio \& G. Dela Cruz-Aguero. 2006. Seasonal seawater temperature as the major determinant for populations of culturable bacteria in the sediments of an intact mangrove in an arid region. FEMS. Microbiol. Ecol. 55: 311-321.

Das, J. \& T.K. Dangar. 2008. Microbial population dynamics, especially stress tolerant Bacillus thuringiensis, in partially anaerobic rice field soils during post-harvest period of the Himalayan, island brackish water and coastal habitats of India. World J. Microbiol. Biotechnol. 24: 1403-1410.

Drozdowicz, A. \& G.M. Ferreira Santos. 1987. Nitrogenase activity in mixed cultures of Azospirillum with other bacteria. Zent. bl. Microbiol. 142: 487-493.

Essien, J.P., S.P. Antai \& N.U. Benson. 2006. Microbial population dynamics as a function of sediment salinity gradients in the qua lboe estuary mangrove swamp (Nigeria). Res. J. Microbiol. 1: 255-265.

Gupta, N., S. Das \& U.C. Basak. 2007. Useful extracellular activity of bacteria isolated from Bhitrkanika mangrove ecosystem of Odisha coast. Malaysian J. Microbiol. 3: 15-18.

Gutknecht, J.L.M, R.M. Goodman \& T.C. Balser. 2006. Linking soil process and microbial ecology in freshwater wetland ecosystems. Plant Soil. 289: 17-34.

Holguin, G., M.A. Guzman \& Y. Bashan. 1992. Two new nitrogen-fixing bacteria from the rhizosphere of mangrove trees: Their isolation, identification and in vitro interactions with rhizosphere Staphylococcus sp. FEMS. Microbiol. Ecol. 101: 207-216.

Holguin, G., P. Vazquez \& Y. Bashan. 2001. The role of sediment microorganisms in the productivity, conservation and rehabitation of mangrove ecosystems: An overview. Biol. Fertil. Soils. 33: 265-278. 
Holguin, G., P.G. Zamorano, L.E. Bashan-De, R. Mendoza, E. Amador \& Y. Bashan. 2006. Mangrove health in an arid environment encroached by urban development-a case study. Sci. Total Environ. 363: 260-274.

Isopi, R., P. Fabbri, M. Del Gallo \& G. Puppi. 1995. Dual inoculation of Sorghum bicolor (L.) Moench ssp. bicolor with vesicular arbuscular mycorrhizas and Acetobacter diazotrophic. Symbiosis 18: 43-55.

Jackson, M.L. 1973. Soil Chemical Analysis. Prentice Hall of India Private Limited, New Delhi, India.

Kathiresan, K. \& M.M. Selvam. 2006. Evaluation of beneficial bacteria from mangrove soil. Bot. Mar. 49: 86-88.

Kathiresan, K. \& N. Rajendran. 2005. Mangrove ecosystem of Indian Ocean region. Indian J. Mar. Sci. 34: 104-113.

Kristensen, E., M.H. Jensen, G.T. Banta, K. Hansen, M. Holmer \& M. King. 1998. Transformation and transport of inorganic nitrogen in sediments of a Southeast Asian mangrove forest. Aquat. Microb. Ecol. 15: $165-175$.

Kristensen, E., S. Bouillon, T. Dittmar \& C. Marchand. 2008. Organic carbon dynamics in mangrove ecosystems: A review. Aquat. Bot. 2: 201-219.

Lageiro, M.M., M.J. Moura, A. Reis \& M.J.C. Ferreira 2007. Microbial proteases application in leather industry. J. Biotechnol. 131: 239-240.

Levin, L.A., D.F. Boesch \& A. Covich et al. 2001. The function of marine critical transition zones and importance of sediment biodiversity. Ecosystems 4: 430-451.

Maria, G.L. \& K.R. Sridhar. 2002. Richness and diversity of filamentous fungi on woody litter of mangroves along the west coast of India. Curr. Sci. 83: $1573-1580$

Martinez, J., D. Smith, G.F. Steward \& F. Azam. 1996. Variability in ecto-hydrolytic enzyme activities of pelagic marine bacteria and its significance for substrate processing in the sea. Aqua. Microbial. Ecol. 10: 223-230.

Mishra, A.K., T.K. Routray \& G.C. Satapathy 1995. Ecological study on Soil Microflora of Bhitarkanika Mangroves in relation to Vegetational Patterns, p. 46-51. In R.C. Mohanty (ed.). Environment: Change and Management. Kamla-Raj, Delhi, India.

Mishra, R.R., T.K. Dangar, B. Rath \& H.N. Thatoi. 2009. Characterization and evaluation of stress and heavy metal tolerance of some predominant Gram negative halotolerant bacteria form mangrove soils of Bhitarkanika, Odisha. Afr. J. Biotech. 8: 2224-2231.

Nannipieri, P., J. Ascher, M.T. Ceccherini, L. Landi, G. Pietramellara \& G. Renella. 2003. Microbial diversity and soil functions. Euro. J. Soil. Sci. 54: 655-670.

Nautiyal, C.S. 1999. An efficient microbiological growth medium for screening phosphate solubilizing microorganisms. FEMS. Microbial. Let. 70: 265-270.

Pelczar, M.J., R.C. Bard, G.W. Burnett, H.J. Conn \& R.D. Demoss. 1957. Manual of Microbiological Methods. McGraw Hill, New York, USA.

Rojas, A., G. Holguin, B.R. Glick \& Y. Bashan. 2001. Synergism between Phylobacterium sp. $\left(\mathrm{N}_{2}\right.$-fixer) and Bacillus licheniformis (P-solubilizer), both from a semiarid mangrove rhizosphere. FEMS. Microbiol. Ecol. 35: 181-187.

Sessitsch, A., A. Weilharter, M.H. Gerzabek, H. Kirchman \& E. Kandeler. 2001. Microbial population structures in soil particle size fractions of a long-term fertilizer field experiment. Appl. Environ. Microbiol. 67: 4215-4224.

Semenov, A.M., A.H. Van Bruggen \& V.V. Zelenev. 1999. Moving waves of bacterial populations and total organic carbon along roots of wheat. Microbial Ecol. 37: 116-128.

Shome, R., B.R. Shome, A.B. Mandal \& A.K. Bandopadhyay. 1995. Bacterial flora in mangroves of Andaman-part 1: Isolation, identification and antibiogram studies. Indian J. Mar. Sci. 24: 97-98.

Sneath, P.H.A. 1986. Endospore forming Gram positive rods and Cocci, p. 1104-1140. In P.H.A. Sneath, N.S. Main, M.E. Sharp \& J.G. Holt (eds.). Mannual of Systematic Bacteriology. Halt Bergeys Williums and Wilkins, Baltimore, USA.

Steinke, T.D. 2000. Mangrove fungi on dead prop roots Rhizophera mucronata at three locations in South Africa. S. Afr. J. Bot. 66: 91-95.

Takizaqa, M., R.R. Colwell \& R.T. Hill. 1993. Isolation and diversity of actinomycetes in the Chesapeake Bay. Appl. Environ. Microbiol. 59: 997-1002.

Thatoi, H.N. \& A.K. Biswal. 2008. Mangroves of Odisha coast: floral diversity and conservation status. Special habitats and threatened plants of India. ENVIS Wild life and protected area. 11: 201-207.

Thatoi, H.N, A. Ouseph, P.K. Mishra, J.R. Mohanty, L.N. Acharjyo \& R.J. Ranjit Daniels. 1999. Mangrove 
restoration in Odisha, South India: An experiment. Tiger paper 26: 23-26.

Toledo, G., Y. Bashan \& A. Soeldner. 1995. Cyanobacteria and black mangroves in Northwest Mexico: Colonization and diurnal and seasonal nitrogen fixation on aerial roots. Can. J. Microbiol. 41: 999-1011.

Wang, Y. \& K. Hong. 2005. Effects of soil factors on microbe distributions in mangrove soil. Chin. J. Trop. Crops. 26: 109-114.
Zaharan, H.H. 1997. Diversity adaptation and activity of the bacterial flora in saline environments. Biol. Fertil. Soils 25: 211-223.

Zhang, Y., J. Dong, B. Yang, J. Ling, Y. Wang \& S.I. Zhang. 2009. Bacterial community structure of mangrove sediments in relation to environmental variables accessed by $16 \mathrm{~S}$ rRNA denaturing gradient gel electrophoresis fingerprinting. Scientia Marina 73: 487-498. 